\title{
Action of nitric acid on carbonate of lime
}

\section{Barreswil}

To cite this article: M. Barreswil (1843) Action of nitric acid on carbonate of lime, Philosophical Magazine Series 3, 23:149, 78-79, DOI: 10.1080/14786444308644694

To link to this article: http://dx.doi.org/10.1080/14786444308644694

册 Published online: 30 Apr 2009.

Submit your article to this journal

Џ Article views: 2

Q View related articles $₫$ 
order to prevent any admixture of silica by using an agate mortar, the mineral was powdered in a steel mortar. 'The powder was digested in hot hydrochloric acid and carefully washed, in order to dissolve the iron acquired from the mortar; it was then dried and weighed. It was then fused at a low red heat in a platina crucible with six times its weight of freshly-prepared bisulphate of potash. In half an hour the fusion and decomposition of the mineral were complete; the mass was dissolved in boiling water and filtered; there remained but a few unimportant particles of micaceous or siliceous matter arising from an accidental admixture. The clear solution was saturated with ammonia; the alumina, glucina and oxide of iron were thus precipitated and separated from the bisulphate of potash.

In order to separate the alumina and oxide of iron from the glucina, they were at first dissolved in a slight excess of hydrochloric acid, and the solution was poured into a large quantity of solution of carbonate of ammonia, which precipitated the alumina and oxide of iron and retained the glucina; but by this method only about 12 of every 100 parts of glucina could be obtained.

This process was therefore abandoned, and the method employed by M. Awdejew was adopted; this consists in dissolving the recently precipitated almmina and glucina in a cold solution of potash, the oxide of iron is thus separated; the alkaline solution is then to be diluted, and on boiling it, glucina is precipitated in white Hocks, which are easily washed; it dissolves entirely in acids and in excess of carbonate of ammonia; the alumina retained in solution by the potash is precipitated in the usual manner.

The oxide of iron was observed in each operation to carry with it a notable quantity of glucina; in order to separate them they were dissolved in hydrochloric acid; the solution was supersaturated with carbonate of ammonia, and the iron was precipitated with hydrosulphate of ammonia. The glucina was separated by boiling the solution from which the sulphuret of iron had been precipitated; and after washing and heating to redness it was added to that previously obtained.

The mean of three analyses gave as the composition of cymophane,-

$$
\begin{array}{llr}
\text { Alumina } \ldots \ldots \ldots \ldots & 75.26 \\
\text { Glucina } \ldots \ldots \ldots \ldots & 18 \cdot 46 \\
\text { Peroxide of iron } \ldots \ldots & 4.03 \\
\text { Sand } \ldots \ldots \ldots \ldots & \frac{1.45}{99 \cdot 20}
\end{array}
$$

M. Damour remarks, that not knowing any mode by which to determine directly the degree of oxidizement of iron in minerals not acted upon by acids, he leaves undecided the question as to the mode of its existence in the cymophane, as to whether it is in the state of protoxide, or of peroxide isomorphous with alumina.-Ann. de Ch. et de Phys., Fev. 1843.

ACTION OF NITRIC ACID ON CARBONATE OF LIME. BY M. BARRESWIL.

It is generally admitted by chemists as a fact, that marble is not 
acted upon by nitric acid of the greatest density. M. Barreswil, desirous of ascertaining whether this anomaly was due to the same want of action of this acid on certain metals, kept a piece of marble in concentrated nitric acid, and it was not visibly acted upon. It was then removed from the acid, washed, dried and powdered, and the powder was put into fresh concentrated acid; it was strongly acted upon, but not entirely dissolved. A little water was then added to the acid, the reaction again took place, and after some time ceased, but recommenced on the addition of more water. It may be concluded from these facts that marble is attacked by concentrated nitric acid with energy proportional to its surface, becoming covered with a varnish of nitrate of lime insoluble in concentrated nitric acid. This nitrate of lime concentrates the nitric acid in which it is produced, and renders it strong. The experiment performed in a direct mode was perfectly conclusive : dried nitrate of lime, put into nitric acid of moderate strength, concentrated and rendered it fuming. - Ibid.

\section{METEOROLOGICAL OBSERVATIONS FOR MAY 1843.}

Chiswick.-May 1. Cloudless : cold and dry. 2. Fine. 3. Very fine. 4. Cloudy and fine: rain. 5. Rain : cloudy: constant and very heavy rain at night. 6. Ileavy rain : clear and cold at night. 7 . Clear and fine : showery : frosty at night. 8. Hazy : heavy rain. 9. Drizzly : cloudy. 10. Slight haze : clear and cold at night. 11. Light haze : clear. 12, 13. Very fine. 14. Cloudy and fine: heavy rain at night, 15, 16. Rain. 17. Heavy showers. 18. Densely overcast : cold rain. 19. Rain : cloudy. 20. Cloudy : showery : heavy rain at night. 21. Fine : heavy rain: clear and cold at night. 22. Heavy showers, 23. Cloudy: lightning with rain at night. 24. Heavy rain : clear. 25. Cloudy and fine. 26. Rain. 27, 28. Showery. 29. Hazy. 30. Light haze: very fine: showery. 21. Cloudy and mild.-Mean temperature of the month $3^{\circ}$ below the average. The quantity of rain was greater than that which has fallen in any month within at least the last seventeen years.

Boston.-May 1, 2. Fine. 3. Cloudy. 4. Fine. 5. Cloudy : rain early a.m. 6. Rain : rain A.M. and P.M. 7. Cloudy. 8. Cloudy : rain P.Mr. 9-11. Cloudy. 12. Fine. 13. Cloudy : rain P.M. 14. Fine. 15. Rain : rain P.M. 16. Cloudy ; rain early A.s. 17. Cloudy. 18, 19. Cloudy : rain early A.M. 20. Cloudy. 21. Cloudy : rain early A.M. : rain P.M. 22. Fine. 23. Cloudy : rain A.M. 24. Windy : rain A.M. 25. Fine: rain A.M. 26. Fine, 27. Fine : rain, with thunder and lightning P.M. 28, 29. Fine. 30. Fine: halo round the sun 11 A.M. 31. Cloudy : rain early A.M. This has been the wettest May we have had since 1830.

Sandwick Manse, Orhney,-May 1. Fine: fog. 2. Cloudy : fog. 3. Clear : cloudy. 4. Rain : cloudy. 5. Cloudy : clear. 6. Clear : cloudy. 7. Rain : cloudy. 8. Clear. 9. Clear : cloudy. 10,11. Clear : fine. 12-14. Cloudy. 15-17. Clear. 18. Cloudy : fine. 19. Cloudy : showers. 20. Bright: clear. 21. Bright: cloudy. 22-24. Bright: clear. 25. Rain. 26. Cloudy. 27. Damp. 28. Cloudy : sleet-showers. 29. Snow-showers : sleet-showers. 30. Bright : fine. 31. Clear : fine.

Applegarth Manse, Dumfries-shire.-May 1-9. Fair and fine. 4. Fair till P.a.: : rain. 5. Heavy showers. 6. Fair and tine. 7. A shower. 8, 9. Fair. 10, 11. Fair : hoar-frost. I2. Fine : rain P.M. 13. Fine and mild. 14. Fine, but cloudy. 15. Showers. 16. Cloudy and cold. 17. Cool : cloudy. 18. A shower. 19. Cold. 20. Cold : fair. 21. Cold : wet. 22. Milder, but showery. 23. Mild : cloudy. 24. Cold and rainy. 25. Soft rain. 26. Mild: showers. 27. Mild : showery. 28. Cold and rainy, 29. Clear: heavy rain, 30. Soft; growing: thunder. 31 . Wet all day. 